\title{
Disturbances in the Mechanism of Apoptosis as One of the Causes of the Development of Cancer Diseases
}

\author{
Zaburzenia mechanizmu apoptozy jako jedna z przyczyn rozwoju chorób nowotworowych
}

\author{
Paweł Rusin ${ }^{1}$, Karolina Jabłońska ${ }^{2}$ \\ ${ }^{1}$ Institute of Biological Sciences, Cardinal Stefan Wyszyński University in Warsaw, Poland \\ ${ }^{2}$ Student Club of Molecular Biology, Cardinal Stefan Wyszyński University in Warsaw, Poland \\ ORCID: PR https://orcid.org/0000-0002-9438-5700・p.rusin@uksw.edu.pl \\ Received: 24 July 2020; Revised: 27 Sep 2020; Accepted: 09 Oct 2020
}

\begin{abstract}
Apoptosis is a genetically programmed process that affects all multicellular organisms. This mechanism of programmed cell death is designed to protect the body against uncontrolled proliferation of cells with impaired functions. Apoptosis can occur through two major pathways. The extrinsic, initiated by signals from the death receptor, and the intrinsic one, resulting from a change in the permeability of the external mitochondrial membrane due to stress factors promoting the initiation of programmed cell death. Apoptosis may be influenced by many factors that may lead to suppressing the initiation of apoptotic pathways, and the damaged cell will develop, divide, and over time transform into a cancerous cell. As a result, cancer cells will be resistant to the applied chemo- and radiotherapy. The mechanisms responsible for apoptosis regulation are impaired, what eliminates the effects of therapies aimed at initiating this type of cell death. New types of molecular therapies provide an opportunity to increase the effectiveness of anticancer treatment, aiming at deficient proteins and suppressing or eliminating their antiapoptotic effects.
\end{abstract}

Keywords: apoptosis, cancer, disorders of the apoptotic mechanisms, targeted treatment

Streszczenie: Apoptoza jest genetycznie zaprogramowanym procesem, obejmującym wszystkie organizmy wielokomórkowe. Ten mechanizm programowanej śmierci komórkowej ma na celu zabezpieczyć organizm przed niekontrolowanym namnażaniem się komórek o zaburzonych funkcjach. Do aktywacji apoptozy prowadzą dwa główne szlaki. Szlak zewnętrzny aktywowany przez sygnały odbierane przez receptory śmierci oraz szlak wewnętrzny, który jest wynikiem zmiany przepuszczalności zewnętrznej błony mitochondrium na skutek działania czynnika stresowego. Na apoptozę wpływ ma wiele czynników, które mogą doprowadzić do supresji inicjacji szlaku apoptotycznego, a uszkodzona komórka będzie rozwijać się, dzielić, a z czasem przekształcić się w komórkę nowotworową. Powstające w ten sposób nowotwory są oporne stosowaną chemio- i radioterapię, gdyż mechanizmy odpowiedzialne za apoptozę są upośledzone, co niweluje działania terapii mających zainicjować ten typ śmierci komórkowej. Szansą na zwiększenie efektywności leczenia są terapie molekularne, które celują w niewłaściwie funkcjonujące białka, niwelując ich antyapoptotyczne działanie.

Słowa kluczowe: apoptoza, nowotwory, zaburzenia mechanizmu apoptozy, terapia celowana 


\begin{abstract}
Abbreviations: Apaf-1 - apoptotic protease activating factor 1; Bcl-2 - B-cell lymphoma 2 protein; BH - Bcl-2 homology; BID - BH3 interacting domain death agonist; CARD - caspase activation recruitment domain; DED death effector domain; DISC - death-inducing signalling complex; FADD - Fas-associated death domain; HSP - heat-shock proteins; IAP - inhibitors of apoptosis proteins; MOMP - mitochondrial outer membrane permeabilization; PCD - programmed cell death; TNFR - tumour necrosis factor cell receptors; TRADD - TNF-R1 associated death domain protein.
\end{abstract}

\section{Introduction - characteristics of apoptosis}

In all higher organisms, mitotic divisions increase the number of new cells. Programmed cell death is one of the most important mechanisms of controlling proper development of organisms. It ensures maintaining the balance between the appearance of new cells and the removal of old, damaged, or unnecessary ones.

There are two types of cellular death which differ in the type of stimuli initiating them, the way of stimulation, molecular triggers, paths of that kind of processes and the easiness of activation after therapeutic intervention. One of the types of cell death is necrosis, which usually manifests itself as the result of sudden and severe cellular damage that leads to the immediate stoppage of metabolism, loss of permeability of cell membranes, inflammation stage and damage of the nearest tissues. The second one is apoptosis, otherwise known as type I of programmed cell death (PCD), it is a genetically programmed process that requires the expression of many genes, specific proteins activation and constant energy input. This active and highly ordered process plays a major role in maintaining homeostasis, removing unnecessary, harmful, or infected cells without inducing inflammation or damage of nearby cells (Pistritto et al. 2016, 603-619).

Apoptosis can be induced by physiological or environmental stimuli. The following phases of that process are distinguished: Initiation - activation of the death signal pathways; Executive - signals are processed, proteolysis, nucleolysis, cellular organelle degradation and activation of executive enzymes occurs; Destruction - degradation of cell structures and components, production of apoptotic bodies and their phagocytosis occur at that phase (Kaźmierczuk and Kiliańska 2010, 273-283).

There are two main routes that may lead to apoptosis: extrinsic and intrinsic. Extrinsic path involves cell surface death receptors. Intrinsic path is activated after the damage of the mitochondrial membrane permeability resulting in the releasing of cytochrome $\mathrm{C}$. In both apoptotic pathways, the caspase family proteins play a crucial role, and their subsequent transformations lead to the breakdown of cell components and cell death. Changes or disturbances in the functioning and expression of proteins controlling these processes may lead to the development of cancer cells resistant to chemotherapy and radiotherapy (Hajra and Liu 2004, 691-704). As a result, cancer cells differ from normal cells dividing and becoming invasive. They produce their own growth factors and are insensitive to external factors inhibiting proliferation, infiltrate the surrounding healthy tissues and cause inflammation (John 2001, 429-431; Madej 2014, 136-146).

There is also an alternative pathway that leads to cell apoptosis called pseudo-receptor pathway. Cytotoxic lymphocytes T and NK (natural killers) activate this type of pathway. Cytolytic granules of these lymphocytes containing perforins form pores in the cell membrane through which granules pass, causing lysis of cellular structures in the cytoplasm and the cell nucleus (Przybylski, Wielikdzień and Kopiński 2013, 1374-1390).

The main problem in the treatment of cancer is the abrogation of undergoing apoptosis. Insensitivity of cells to signals from death receptors after chemotherapy is caused by overexpression of proteins inhibiting apoptosis. There is a new hope for treatment involving molecular therapies that will activate the mechanism of the intrinsic 
apoptotic pathways or control the expression of proteins that initiate cell death (Pistritto et al. 2016, 603-619).

\section{Main mechanisms leading to apoptosis}

Two major pathways lead to programmed cell death: the extrinsic pathway, which involves cell surface death receptors; and the intrinsic pathway activating mitochondria. Both pathways involve the activation of a cascade reaction of cysteine protease family enzymes called caspases. The caspases are initially synthesised as proenzymes and after activation are modified to active forms. Both pathways have a set of independent groups of initiating and effector caspases that trigger cell death (Hajra and Liu 2004, 691-704).

\subsection{Extrinsic apoptotic pathway}

The initiation of the extrinsic apoptotic pathway is caused by the interaction between cell surface exposed death receptors, belonging to the superfamily of tumor necrosis factor cell receptors (TNFR) with their ligands. The death receptors have an intracellular domain, which is a separate protein element capable of maintaining its structure independently of the rest of the receptor. This independent domain is called the Death Domain (DD) and it plays a critical role in transmitting the death signal from the cell surface to the intracellular signaling pathways. After stimulation of the death receptors by the appropriate ligands, their structure changed and the activated Death Domain interacted with another protein containing DD formatting oligomers. The next step is to transfer the signal from the death domain to adapter proteins (Pistritto et al. 2016, 603-619; Kaźmierczuk and Kiliańska 2010, 273-283). Adapter proteins FADD (Fas-associated death domain) and TRADD (TNF-R 1 associated death domain protein) are activated by $\mathrm{DD}$, that protein complex activates inactive forms of caspases - procaspase- 8 and/ or procaspase-10 by death effector domain (DED) during death-inducing signaling complex (DISC) formation (Pistritto et al. 2016,
603-619). Activation of these proteins starts the caspase cascade and a breakdown of cellular structures. After changes in cytosol, a gradual disintegration of the cell nucleus starts, which leads directly to the fragmentation of the cell's DNA into short fragments of different sizes, which can be observed as an apoptotic ladder in gel after electrophoresis (Kaźmierczuk and Kiliańska 2010, 273-283). Activation of initiator caspases (caspase- 8 and -10) causes the processing of effector caspases-3, -6 and -7 , activation of which leads to the cleavage of essential substrates for cell viability and inducing cell death. Some cells, however, do not undergo apoptosis as a result of the extrinsic pathway and require additionally duplication of signaling induced by caspase-8. Activated caspase 8 has the ability to cleave and activate the proapoptotic $\mathrm{BH}_{3}$-only protein family - $\mathrm{BID}\left(\mathrm{BH}_{3}\right.$ interacting domain death agonist), leading to C8-BID complex formation, which can simultaneously initiate the intrinsic apoptotic pathway, activating their $\mathrm{t}$-Bid ligand responsible for the activation of a proapoptotic multi-domain proteins, which activity interferes with the loss of permeability of the external mitochondrial membrane (Pistritto et al. 2016, 603-619).

\subsection{Intrinsic apoptotic pathway}

The intrinsic or mitochondrial apoptotic pathway is activated independently of death receptors and results in the activation of effector caspases (Hajra and Liu 2004, 691704). It is mediated by intracellular signals that focus around the mitochondria and in response to stress conditions such as irritation, treatment with chemotherapeutic agents, genetic defects, hypoxia, increased concentration of calcium ions, oxidative stress, etc. Proapoptotic $\mathrm{BH}_{3}$-only proteins from the Bcl-2 family (Bax, Bak), which are called "apoptosis switches", are activated. They neutralize the effects of antiapoptotic proteins from the same family: Bcl-2, Bcl-xL, Mcl-1. This activity leads to abnormal permeability of the external mitochondrial membrane, and mitochondrial 
intermembrane space proteins are released to the cytosol. One of the most important of the proapoptotic mitochondrial origin factors - cytochrome $\mathrm{c}$ is released that way. $\mathrm{Cy}-$ tochrome c plays a crucial role in activating cell death by the mitochondrial pathway, incorporating the cytoplasmic protein Apaf-1 (apoptosis protease activating factor-1) and it triggers the formation of a complex called apoptosome. Initiator procaspase-9, thanks to its internal CARD domain (caspase activation recruitment domain) has the ability of autoactivating and then decomposing protein structures. This process is activated by the executor caspase- $3,-6$ and -7 , which starts degradation of cell structures, resulting in apoptotic cell death (Pistritto et al. 2016, 603-619).

\section{Role of caspases in apoptosis activation}

In cells passing through the apoptosis process, specified biochemical processes and changes in cell morphology can be observed, including: cellular contraction, fragmentation of the nucleus, DNA cleavage, chromatin condensation, loss of mitochondrial membrane, changes in cell membrane composition, formation of apoptotic bodies, activation of caspases, protein phosphorylation, synthesis of RNA and proteins required for the apoptotic death cell process (Nuñez et al. 1998, 3237-3245; Kaźmierczuk and Kiliańska 2010, 273-283). Elimination of caspase inhibitors leads to most of these cellular changes (Nuñez et al. 1998, 3237-3245).

\section{Regulation of caspases activation by Bcl-2 proteins family}

Bcl-2 proteins (B-cell lymphoma 2 protein) are described as "apoptosis switches", which control both proapoptotic and antiapoptotic processes. This group of proteins that regulate the induction of mitochondrial outer membrane permeabilization are called MOMP and are considered as the "point of no return". They are responsible for the cascade of numerous apoptotic pathways in cell death processes.
That kind of protein can be divided into three subgroups due to the $\mathrm{BH}$ domains composition ( $\mathrm{Bcl}-2$ Homology). The first subgroup of proteins producing antiapoptotic effects includes Bcl-2, Bcl-xL, Bcl-W, Mcl-1, A1, and Bcl-B. The second subgroup of $\mathrm{Bcl}-2$ are proapoptotic proteins $\mathrm{Bax}, \mathrm{Bak}$ and Bok. The third subgroup $\mathrm{Bcl}-2$ $\mathrm{BH}$ 3-only subfamily members, including Bid, Bim, Bad, Puma, Noxa, BMF, HRK and BIK, this group includes proteins that also exert an proapoptotic effect. The $\mathrm{Bcl}-2$ proteins prevent apoptosis by blocking cytochrome c release from mitochondria, while proapoptotic proteins promote its release. The balance between the pro- and antiapoptotic $\mathrm{Bcl}-2$ proteins effects determines the sensitivity of the cells to apoptotic stimuli.

Activation of the $\mathrm{BH}_{3}$-only proapoptotic signaling proteins Bax and Bak conducts its translocation from the cytosol to the mitochondrial membrane, which results in oligomerization of $\mathrm{Bax} / \mathrm{Bak}$, leading to the formation of pores on the surface of the external mitochondrial membrane.

Some of the Bcl-2 family proteins prevent apoptosis not only by eliminating the Bax and Bak proteins, but also by preventing accumulation of calcium ions in the endoplasmic reticulum by reducing its capacity.

Cytochrome $\mathrm{C}$ is the first proapoptotic protein released from the mitochondria into the cytoplasm, other released mitochondrial proteins including apoptosis-inducing factor (AIF) contribute to apoptotic nuclear DNA damage in a caspase-independent way. Further examples of released proteins are Smac/ DIABLO (second mitochondria-derived activator of caspase/direct IAP-binding protein with low PI) and the serine protease HtrA2/ OMI (high-temperature requirement protein A2), which both promote caspase activation and initiation of caspase-independent cytotoxicity (Gregorczyk et al. 2014, 456-459; Pistritto et al. 2016, 603-619). 


\section{The role of cytochrome $C$ and Apaf-1 in the regulation of apoptosis activation}

The key element of the mitochondrial transport system, cytochrome $\mathrm{C}$, is also essential to activating the caspase cascade. When it is released into the cytosol from the interstitial space of the mitochondria, it stimulates the activity of the initiatory caspases.

In the cytosol, cytochrome $\mathrm{C}$ binds to the apoptotic protease activating factor $1-$ Apaf-1 protein and in the presence of ATP, formatting the apoptosome. After changes in Apaf-1 protein structure, it is able to connect with procaspase 9 and activate it (Nuñez et al. 1998, 3237-3245).

\section{Heat shock proteins}

Heat-shock proteins (HSPs) have both proapoptotic and antiapoptotic properties and they have the ability to bind and interact with numerous cell structures. Heat-shock proteins have dual roles as regulators of protein conformation and stress sensors, that is why its activity may lead to cell proliferation or apoptosis. They can implement changes to the process of programmed death in its early stages by silencing the expression of genes encoding proteins involved in the death signal pathways. What is more, they are capable of inhibiting the activity of the proteins of the apoptosis pathway. Their activity weakens or even blocks death signaling and reduces the activity of apoptosis-related proteins by enabling cellular injury repair and elimination of any sign of cellular stress. The synthesis of heat shock proteins prevents apoptosis induced by various factors, and their level in cells is sufficient to control this process. HSPs inhibit the apoptosis process by limiting the maturation or activation of fully functional cysteine proteases.

Excessive synthesis of some HSPs results in inhibition of caspase activation even in case of large amounts of abnormally formed proteins or extensive DNA damage. On the other hand, if the level of HSPs decreased, the cells would too easily take the path of programmed death.

Heat shock proteins participate in the regulation of caspases activity. They are able to inhibit the main apoptosis pathways, both intrinsic and extrinsic, by interacting with the main signaling and executive proteins. For example, it can be observed as changes in signal transmission in the mitochondrial pathway after the detaining process of releasing apoptotic factors from the mitochondria. Heat Shock Proteins have the ability to inhibit later stages of apoptosis, this unique ability is not demonstrated by other regulatory proteins under stress conditions (Kaźmierczuk and Kiliańska 2010, 273-283).

\section{Inhibitor Apoptosis Protein family}

Strict control of the destructive effects of caspases in cells is essential to prevent their premature death. Negative regulation of these groups of proteases is controlled by proteins from the family of apoptosis inhibitors (IAP). In humans, the main representatives of this family are NAIP, cIAP1, cIAP2, XIAP, Survivin, Apollon.

IAP proteins have characteristic BIR domains (baculovirus IAP repeats) mediating interactions with different proteins, enabling the creation of bonds and inactivation of caspases. However, IAP activity can be overshadowed by mitochondrial proteins such as Omi/HtrA2 and Smac/DIABLO after being released into the cytosol. They are able to bind the BIR domain, reducing the ability of IAPs to bind proteases (mainly caspases-3 and -9) allowing for its full activity. The XIAP protein is the best-known protein of the apoptosis inhibitor family. Its activity includes the inhibition of effector caspases activity and preventing the activation of caspase-9 (Pistritto et al. 2016, 603-619).

\section{Protein p53}

P53 protein plays one of the most important roles in the apoptosis process. The signaling pathways involved in p5 3 activation are 
complex and still incompletely understood. This protein is a transcription factor which regulates the expression of many genes encoding proteins participating in the regulation of the cell cycle and cell death signaling. It plays an important role in stopping the cell cycle during DNA repair or leading the cell to the apoptosis path.

The 553 protein has the ability to activate and to inhibit the expression of genes. For example, p53 induces an expression decrease of the apoptosis-suppressing gene $\mathrm{Bcl}-2$, while simultaneously stimulating the increasing expression of Bax, a gene encoding a dominant inhibitor of the $\mathrm{Bcl}-2$ protein.

This protein also participates in the process of caspases activation. It can regulate the activity of proapoptotic proteins from the $\mathrm{Bcl}-2$ family or death receptors. It also influences further stages of apoptosis by regulation of gene expression coding proteins such as: Apaf-1 and caspase- 6 (Nowak and Tarasiuk 2004, 330-343).

\section{Abnormalities in proapoptotic pathways}

\subsection{Inhibition of cytochrome $C$ release}

Release of cytochrome $\mathrm{C}$ from the intermembrane space of the mitochondria to the cytosol is necessary for the initiation of the intrinsic apoptotic pathway. The proteins of $\mathrm{Bcl}-2$ family are responsible for proper release or inhibition of cytochrome $\mathrm{C}$ release from mitochondria. A dynamic balance of these oppositely acting proteins determines if a cell will survive or whether it will be led to the apoptosis pathway. Antiapoptotic proteins suppress the release of cytochrome $\mathrm{C}$ into the cytosol by blocking the formation of the apoptosome and stopping the activation of the caspases. The proapoptotic Bax and $\mathrm{BH}_{3}$-only proteins are agonists of antiapoptotic proteins from the same $\mathrm{Bcl}-2$ family. The activator $\mathrm{BH}_{3}$ proteins - $\mathrm{tBid}$, Bim, and Puma - bind to both the proapoptotic and the antiapoptotic $\mathrm{Bcl}-2$ proteins. The $\mathrm{BH}_{3}$ proteins - Bad, Noxa, Bik, Bmf, Hrk, and Bnip3 - bind to the antiapoptotic proteins, releasing activator $\mathrm{BH}_{3}$ proteins to promote mitochondrial outer membrane permeabilization (MOMP). The antiapoptotic proteins bind to both the activator and sensitizer $\mathrm{BH}_{3}$ proteins but are unable to create complexes with Bax and Bak. Therefore, for a cell to evade apoptosis, the antiapoptotic proteins must inactivate the $\mathrm{BH}_{3}$ proteins to prevent Bax/Bak activation and initiate apoptosis.

However, the outflow of cytochrome $\mathrm{C}$ is not sufficient to initiate apoptosis, what was shown in a study of determining mechanisms causing the programmed death of breast cancer cells. In healthy cells, the cascade reactions of caspases should have been initiated by cytochrome $\mathrm{C}$ release. Nevertheless, in case of breast cancer cells no such reaction occurred, there are a number of mechanisms inhibiting cytochrome $\mathrm{C}$ activity in cancer cells (Hajra and Liu 2004, 691-704).

\subsection{The inhibition of apoptosome formation}

Apoptosome is a complex, made up of four components, including cytochrome $\mathrm{C}$, apoptosis-activating factor 1 (Apaf-1), adenosine triphosphate (ATP), and procaspase-9. Apoptosome formation starts after cytochrome $\mathrm{C}$ release from the mitochondria to the cytosol. The modulation of apoptosome formation is a balance between pro-apoptotic and anti-apoptotic signals (Hajra and Liu 2004, 691-704).

Heat shock proteins are induced in response to a variety of stress factors. These proteins have been found to inhibit apoptosome formation and suppress apoptosis in response to physiological and environmental stresses. The HSP7o has the ability to bind to the CARD domain of the Apaf-1 and does not allow for the activation of caspase 9, which is responsible for the start of caspase reaction. Other heat shock proteins also have a role in blocking the initiation of programmed cell death. HSP9o does not allow the apoptosome formation by binding and inactivating the Apaf-1 proteins. $\mathrm{HSP}_{27}$ binds to cytochrome $\mathrm{C}$ and procaspase-3, blocking the further execution 
of the apoptosome formation (Hajra and Liu 2004, 691-704).

\subsection{Changes in caspases activation}

Proteins responsible for regulating the intrinsic apoptosis pathway cause changes in the caspase activation process. The inhibitors of apoptosis proteins (IAPs) have been described in cases of arthropod viral infection caused by baculoviruses. In humans, numerous IAPs have also been described: XIAP, cIAP1, cIAP2, NIAP, BRUCE, ML-IAP and Survivin. Each of these proteins has at least one BIR (baculoviral IAP repeat) domain consisting of about 70 amino acids, that enables apoptosis suppression. The BIR 1 and $\mathrm{BIR}_{3}$ domains bind caspases -3 and -7 to block their action. The $\mathrm{BIR}_{3}$ shows a similarity to caspase-9 and is able to inhibit its action. This domain can be found in proteins like XIAP, cIAP1 and $\mathrm{CIAP}_{2}$. When overexpression of these proteins occurs in the cell, the caspase reaction may be stopped or may not be initiated at all (Hajra and Liu 2004, 691-704).

The caspase activation will also be stopped in the extrinsic pathway. FLIP (FLICE inhibitory protein), which is significant to contain apoptosis progression, contributes to this. Its action leads to binding FADD adaptive proteins and disturbing the process of cascade- 8 activation. Moreover, during the early stages of the extrinsic pathway, they inhibit signal transmission by TRAIL receptors (Nowak and Tarasiuk 2004, 330-343).

\section{Dysfunction of the apoptotic receptor pathway as a cause of cancer}

Gene mutations responsible for the abnormal formation of the TRAILR receptors (tumor necrosis factor-related apoptosis-inducing ligand-receptor) contribute to the development of cancer. During apoptosis activation, the cells that react in the correct way TRAIL ligands bind to TRAIL-R1 or TRAIL-R2 receptors induce the recruitment of FADD and caspase- 8 to these receptors, forming the membrane
DISC or complex I, in which pro-caspase- 8 is activated what leading to the release of the active caspase- 8 in the cytosol and allowing the engagement of the apoptotic cascade. Mutations in the gene coding TRAILR2 receptors have been identified in various human cancers, such as: breast, lung, larynx, throat, mouth, nose, salivary glands cancers and non-Hodgkin's lymphoma. Some of these mutations were repeatedly recognized in different types of cancers. There are also some of the unknown points of mutations in human cancer cells that have the ability of blocking TRAILR2 receptors, DISC complex formation and as a consequence blocking apoptosis initiation. What is more, TRAILR1 receptors are also involved in signal conduction and dysfunction receptors negatively affect the ability of the signaling ligands binding. Mutations of TRAILR1 have been recognized in prostate and bladder cancer, squamous cell carcinoma including oral cavity, nose, larynx and throat, chronic lymphocytic and myeloid leukemia (Johnstone, Frew and Smyth 2008, 782-798).

Altered regulation of the antiapoptotic FLIP protein can also stand behind cancer development. This protein regulates the activation of caspase- 8 and caspase-10. In cancer cells, its alteration may lead to the contribution of the suppression of apoptosis. An increase of its expression is observed in numerous cancers, including liver, skin, lung, ovarian, endometrial, colorectal, and prostate cancer. Enhanced FLIP is able to block the activation of caspase- 8 and inhibit caspase cascade reactions (Hassan et al. 2014, 1-23).

\section{Malfunction of apoptotic mitochondrial pathway as a cause of cancer}

Disturbances in the apoptosis pathways cause an imbalance between cell growth and death, what may contribute to cancer. Insufficient or lack of signal apoptosis triggers contributes to uncontrolled cell growth. Excessive antiapoptotic signals will immunize the cell against stress stimuli, what may result in an inappropriate 
response to signals and prevent those cells from entering the path of apoptosis.

Various alterations of the intrinsic pathway can be a cause of many types of cancer diseases (Lowe and Lin 2000, 485-495 Hajra and Liu 2004, 691-704). These include overexpression of the $\mathrm{Bcl}-2$ proteins, flawed functioning of Bax protein, and other disorders related to proteins of the mitochondrial pathway (Hajra and Liu 2004, 691-704; Hassan et al. 2014, 1-23). Incorrect synthesis of $\mathrm{Bcl}-2$ proteins leads to an imbalance between pro- and anti-apoptotic signals. Antiapoptotic proteins can promote a contribution to oncogenesis, while their antagonists act as suppressors of cancer. The process of cell transformation into neoplastic cells for the first time has been observed in lymphoma. The role of $\mathrm{Bcl}-2$ in tumor formation has been confirmed during studies on transgenic mice, where overexpression of these proteins has led to the formation of numerous lymphomas. In many types of malignant neoplasms, including breast, pancreatic, prostate cancer and lymphoma, overexpression of $\mathrm{Bcl}-2$ protein has been observed. Homologous $\mathrm{Bcl}-\mathrm{xL}$ protein also has shown overexpression in breast, pancreatic, colorectal cancer, and squamous lymphoma of the esophagus. The resulting cancer cells are resistant to the treatment. However, we can still find proapoptotic proteins, such as Bak and Bax and $\mathrm{BH}_{3}$-only in cancer cells which may suppress cancer cells development (Hannun 1997, 1845-1853; Hajra and Liu 2004, 691-704; Goldar et al. 2015, 2129-2144).

Another protein, whose incorrect activity can lead to oncogenesis is Apaf-1. Inactivation of this element of the apoptosome results in the development of malignant tumors that are difficult to treat. As the cause of stopping the synthesis of this protein is indicated the loss of one of the two gene variants by methylation of one of the alleles. The first reports about the lack of synthesis of this factor occurred in cells of malignant melanoma. Subsequent studies have shown that the frequency of Apaf-1 function loss is higher in the case of metastatic melanomas than in their less aggressive forms. The same mechanism has also been observed in gliomas, leukemia, and ovarian cancer (Pistritto et al. 2016, 603-619).

Inhibition of apoptosome formation may be a result of harmful actions of heat shock proteins and ProT. The HSPs have the ability to suppress apoptosome formation in cells, making them potentially oncogenic. Increased expression of HSPs genes, especially $\mathrm{HSP}_{70}$, contributes to the development of malignant forms of breast, stomach, uterus, and lung cancers, with poor clinical prognosis. Breast cancer, which is the result of this type of disorder characterized by a greater malignancy of the tumor and resistance to chemotherapy. Another protein that inhibits the formation of the apoptosome - ProT - is detected in malignant cancer cells of the lungs, liver, breast, and colon.

Undesirable changes also occur among caspase activators, such as apoptosis protein inhibitors - IAP. Among them, Survivin contributes most to the development of cancer. Increased synthesis of this protein is observed in many cancers. In vitro studies have shown that reducing the level of this protein in cells restores the proper functioning of apoptotic pathways and sensitized to chemotherapeutics. What is more, overexpression of XIAP contributes to the formation of myelogenous leukemia, and ML-IAP is the cause of melanoma (Lowe and Lin 2000, 485-495; Hajra and Liu 2004, 691-704; Nowak and Tarasiuk 2004, 330-343).

\section{Development of multidrug resistance by cancer cells}

Cancer cells protect themselves by developing drug resistance. There are several mechanisms by which cancer cells avoid the toxic effects of therapeutic agents. Among them, there are active transport mechanisms that use transboundary pumps and passive transport mechanisms by exocytosis. Both kinds of transport remove therapeutic agents from the cell, reducing their concentration 
in cells. Another way of defense is to change the composition of cell structures, which are the target of anticancer drugs. This mechanism is related to the alteration of DNA conformation as well as the performance of repair systems. The permeability of the nuclear membrane is also changed (Nowak and Tarasiuk 2004, 330-343).

In cancer cells, the programmed death is halted by the imbalance between the signals promoting survival and the signals leading to apoptosis, what causes uncontrolled cell development and multidrug resistance (Nowak and Tarasiuk 2004, 330-343).

\section{Molecular methods to restore the appropriate function of the apoptotic mitochondrial pathway}

To increase the effectiveness of anticancer therapies, the main aim is to focus on cellular dysfunction at a molecular level that includes factors involved in the apoptotic mitochondrial pathway. There are some mechanisms which could restore the proper activation of apoptosis in cancer cells by targeting specific elements of the apoptotic pathway.

\subsection{Manipulation of $\mathrm{BCl}-2$ family proteins}

There are two main therapeutic strategies of Bcl-2 family protein manipulation, the first is to restore the correct apoptotic pathways. The second is to induce apoptosis without inputting additional signals into the cells. To achieve that, it is required to reduce the level of protein synthesis to inhibit the cancer development.

For the first approach, to reach an assumed effect is using an antisense strand consisting of 18 nucleotides complementary to the first nucleotide of $\mathrm{Bcl}-2$ DNA encoding strand, it contributes to the blockage of gene expression responsible for $\mathrm{Bcl}-2$ synthesis. The application of this treatment is being tested on patients with advanced breast cancer (Hannun 1997, 1845-1853; Kasibhatla and Tseng 2003, 573-580; Hajra and Liu 2004, 691-704; Hassan et al. 2014, 1-23; Goldar et al. 2015, 2129-2144).

\subsection{Inhibitors of apoptosis proteins (IAPs) incorporation}

This method itself does not contribute to restoring the natural death of cells. Nevertheless, it increases cancer cells sensitivity to chemotherapy (Hajra and Liu 2004, 691-704). There have been discovered many small protein and nonprotein molecules that mimic the Smac domain and bind to IAP proteins. These molecules are able to bound the $\mathrm{BIR}_{2}$ and $\mathrm{BIR}_{3}$ domains of $\mathrm{c}-\mathrm{IAP} 1$ and $\mathrm{C}-\mathrm{IAP}_{2}$ and XIAP proteins. It contributes to increasing the activity of caspases, which are affected by the inhibitory effects of IAPs. In addition to blocking c-IAP and XIAP, the IAPs inhibitors also increased the activity of TRAIL. This method may contribute to the resumption of the apoptotic receptor pathway. It is being tested as a prostate cancer treatment. IAPs may also be used in molecular research to block XIAP and Survivin activity using antisense oligonucleotides. Several antisense nucleotide sequences have been described, which negatively regulate the activity of these proteins, blocking their gene expression. These sequences include AEG35156 and LY2181308, they bind to mRNA encoding Survivin and block gene expression. A small molecule, like YM155, which is an inhibitor for Survivin genes, binds to the gene promoter and blocks protein expression. The use of this mechanism can be applied to different types of cancers (Goldar et al. 2015, 2129-214.4).

\section{Conclusion}

Programmed cell death is a defensive mechanism that induces homeostasis in organisms. It protects the whole organism against the spread of damaged and potentially dangerous cells. The mechanisms of apoptosis consist of multi-stage, complex pathways in which each element plays a significant role. If some regulatory agents fail or start to function in the wrong way, there will be observed intensive cell development and divisions of the wrongly functioning cells, which can lead to cancer. 
Any attempt to restore proper regulation of the cell cycle and apoptosis in such altered cells encounters great resistance. Cells of this type develop mechanisms of defence against stimuli which could contribute to their death. Cells use for this purpose the elements taking part in the regulation of apoptotic pathways, they eliminate or change their activity and become insensitive to external signals. This is why, the standard therapeutic methods are not effective and there are poor prognoses for patients with multiple types of cancers.

Currently, therapeutic methods implement new discoveries of molecular biology and research on mechanisms that control the function and growth of cancer cells looks promising. New therapies target molecules that play an important role in regulation of programmed cell death pathways, which impair functions that contribute to cancer cells resistance to treatment. The changes in the level of synthesis of crucial proteins or the suppression of their activity may allow for the induction of apoptosis or will facilitate the effectiveness of chemotherapy.

Due to observed increasing resistance to chemotherapy and radiotherapy and the toxicity of traditional anticancer therapies, there is a need to find new, non-toxic anticancer therapeutic agents. The optimal therapy would only act on cancer cells. Plant compounds or their derivatives are usually non-toxic to normal cells and many of the plant compounds are suitable for supporting cancer chemotherapy by activating apoptosis. Such compounds include: curcumin, which is an inhibitor of Bcl-2 and XIAP, Aloe vera emodin causing accelerated release of cytochrome $\mathrm{C}$ or 3-galusan epigallocatechin activating cell death receptors (Pfeffer and Singh 2018, 448).

It also turned out that many of the IAPs are excellent predictor factors. It has been discovered that an appropriate level of IAPs $\left(\mathrm{BIRC}_{3}, \mathrm{BIRC}_{5}, \mathrm{BIRC} 6\right.$ and $\left.\mathrm{BIRC}_{7}\right)$ were found to be predictive of sensitivity to BCL-2 inhibitors as well as RIPK1 inhibitors BIRC $3_{3}$ and BIRC6). Cancer cells will be highly sensitive to this type of therapy. This is one of the newer discoveries showing great potential for new targeted therapies using IAP (Liang et al. 2020).

However, every cancer is different and a single type of treatment method is insufficient to effectively overcome this group of diseases. Depending on the type of cancer, the process in which it occurs and the type of damage that contributes to its development, it is necessary to adjust an appropriate molecular mechanism to address the source of the disorder, block the factors that protect the cell from programmed death and combine it with standard treatment methods. That kind of approach may improve the effectiveness of anticancer therapies and mean a better prognosis for patients.

\section{Bibliography}

Goldar, Samira, Mahmoud S. Khaniani, Sima Derakhshan, and Behzad Baradaran. 2015. "Molecular Mechanisms of Apoptosis and Roles in Cancer Development and Treatment." Asian Pacific Journal of Cancer Prevention 16(6): 2129-2144. http://dx.doi.org/10.7314/APJCP.2015.16.6.2129.

Gregorczyk, Karolina P., Zbigniew Wyżewski, Lidia Szulc-Dąbrowska, and Marek Niemiałtowski. 2014. "Hamowanie mitochondrialnego szlaku apoptozy przez białka pokswirusów." Medycyna Weterynaryjna 70(8): 456-459.

Hajra K.M., and J. R. Liu. 2004. "Apoptosome dysfunction in human cancer." Apoptosis 9(6): 691-704.

Hannun, Yusuf A. 1997. "Apoptosis and the Dilemma of Cancer Chemotherapy.” Blood 89(6): 1845-1853. http://dx.doi.org/10.1182/blood.V89.6.1845.

Hassan, Mohamed, Hidemichi Watari, Ali Abu Almaaty, Yusuke Ohba, and Noriaki Sakuragi. 2014. "Apoptosis and Molecular Targeting Therapy in Cancer." BioMed Research International 2014: 1-23. http://dx.doi.org/10.1155/2014/150845.

Johnstone, Ricky, Alisa J. Frew, and Mark Smyth. 2008. "The TRAIL apoptotic pathway in cancer onset, progression and therapy." Nature Reviews Cancer 8: 782-798. http://dx.doi.org/10.1038/ nrc2465. 
Kasibhatla, Shailaja, and Ben Tseng. 2003. "Why Target Apoptosis in Cancer Treatment?" Molecular Cancer Therapeutics 2(6): 573-580.

Kaźmierczuk, Arletta, and Zofia M. Kiliańska. 2010. "Rola białek szoku cieplnego w apoptozie komórek." Postępy Higieny i Medycyny Doświadczalnej 64: 273-283.

Liang, Jianfeng, Wanni Zhao, Pan Tong, Ping Li, Yuanli Zhao, Hua Li, and Jun Liang. 2020. "Comprehensive molecular characterization of inhibitors of apoptosis proteins (IAPs) for therapeutic targeting in cancer." BMC Medical Genomics 13: 7. http://dx.doi.org/10.1186/s12920-020-0661-x.

Lowe, Scott, Athena W. Lin. 2000. "Apoptosis in cancer." Carcinogenesis 21(3): 485-495.

Nowak, Robert, i Jolanta Tarasiuk. 2004. "Hamowanie procesu apoptozy w komórkach nowotworowych opornych na działanie leków przeciwnowotworowych." Postępy Biochemii 50(4): 330-343.

Nuñez, Gabriel, Mary A. Benedict, Yuanmimg $\mathrm{Hu}$, and Naohiro Inohara. 1998. "Caspases: the proteases of the apoptotic pathway." Oncogene 17: 3237-3245.

Pfeffer, Claire M. and Singh T. K. Amareshwar. 2018. "Apoptosis: A Target for Anticancer Therapy." International Journal of Molecular Sciences 19(2): 448. http://dx.doi.org/10.3390/ijms19020448.

Pistritto, Giuseppa, Daniela Trisciuoglio, Claudia Ceci, Alessia Garufi, and Gabriela D’Orazi. 2016. "Apoptosis as anticancer mechanism function and dysfunction of its modulators and targeted therapeutic strategies." Aging 8(4): 603-619. 